\title{
The Philosopher's Medicine of the Mind: Kant's Account of Mental Illness and the Normativity of Thinking
}

\author{
Krista K. Thomason
}

Contemporary readers are unlikely to turn to Kant for insights into mental illness. First, his account of mental illness contains classifications that are often fluid and ambiguous. Even though he seems to offer taxonomies, it is unclear how serious he is about them. Second, since Kant is widely read as a champion of the power of reason and mental self-mastery, readers might expect him to dismiss mental illness as weakness. In his moral philosophy, for example, he argues that a human being must "bring all his capacities and inclinations under his (reason's) control" (MM 6: 408). He describes the medical science as "philosophical" when "the sheer power of man's reason to master his sensuous feelings by a self-imposed principle determines his manner of living" (Medicine 7: 101). Claims like these make it seem as though Kant might blame people with mental illnesses for failing in their obligations of self-mastery. In spite of these apparent disadvantages, I argue that Kant's account of mental illness is illuminating with regard to his views about the normativity of thinking and that it is not as

K. K. Thomason $(\bowtie)$

Department of Philosophy, Swarthmore College, Swarthmore, PA, USA

(C) The Author(s) 2021

A. Lyssy, C. Yeomans (eds.), Kant on Morality, Humanity, and

Legality, https://doi.org/10.1007/978-3-030-54050-0_10 
callous as it might seem. Here I argue that Kant's account of mental illness is best understood as part of his applied logic. The domain of applied logic is partly to identify obstacles that human beings will face as they try to apply the rules of thinking in their lives. On Kant's view, mental illness is one such obstacle. Mental illness causes our thinking to become disordered, and once this occurs, Kant argues that we cannot simply will it back to order. Although Kant does prescribe a "diet of the mind," he nevertheless does not believe that mental illnesses are the result of a failure to exercise one's cognitive powers properly (Maladies 2: 271). I argue that Kant has a nuanced view of both the causes and treatments for mental illness. Additionally, I argue that his view is both compassionate to people who suffer from mental illness and is consistent with his commitments to rational self-governance.

\subsection{BaCKGround AND OVERVIEW}

Kant's account of mental illness is influenced by his historical context, so it is important to briefly introduce some of the ideas about mental illness that were present in Kant's day. First, eighteenth-century conceptions of mental illness are difficult to categorize. A wide range of behaviors and conditions counted as madness and many of them do not match present methods of classification (Lindemann 1999, 28-32). What is more, there was disagreement among medical writers about the categories and causes of mental illness (Lindemann 1996, 262-265; 1999, 31-33). Although Galenic humoralism was still influential in the eighteenth century, there were also proponents of vitalism, environmentalism, and iatrochemistry (Lindemann 1999 8-10 and 85-90). Different theories and causes of disease led to different recommendations for cures and therapies. As Lindemann puts it, "Eighteenth-century medicine contained bits and pieces of all these 'systems,' and they were all to be found in discussions of what caused disease and what health was" (Lindemann 1996, 265).

We know Kant kept abreast of the developments in medicine and health during his lifetime (Wiesing 2008, 221 and Foucault 2008, 109-112). Kant regularly corresponded with Marcus Herz, his friend and former student, who was a practicing physician in Berlin, and he commented Samuel Thomas Soemmering's On the Organ of the Soul (Zammito 2018, 434). At least two of the more influential medical writers of the time period appear in Kant's work: Christoph Hufeland and John Brown. Hufeland sent Kant a copy of his Die Kunst das menschliche Leben zu 
verlängern (The Art of Prolonging Human Life), on which Kant commented (Unna 2012, 273-274). Kant's reply eventually became his essay "On the Power of the Mind to Master its Morbid Feelings by Sheer Resolution. A Letter in Reply to Privy Councillor and Professor Hufeland." Hufeland's work was one of the influential texts of the period and was written for a popular audience (Lindemann 1996, 262-264). Also influential in the time period was the work of John Brown, the Scottish author of Elementa medicina (Wiesing 2008, 222 and Lindemann 1996, 264-265). Kant references Brown's work in the Anthropology and the Metaphysics of Morals (Anth 7: 255 and MM 6: 208). Characteristic of both Hufeland and Brown (as well as other writers at the time) was (a) an emphasis on dietetics (preventing illness with health regimens) and (b) a loose distinction between mental and physical health (Lindemann 1996, 263-265; 1999, 30-32). As we will see, Kant's own thoughts about health and mental illness share these characteristics.

Providing an overview of Kant's conception of mental illness is challenging because it is unclear exactly how systematic his views are. ${ }^{1}$ Additionally, there is some debate about precisely what Kant means by "mind" or "mental." Kant's primary remarks on mental illness are found in Anthropology from a Pragmatic Point of View, Essay on the Maladies of the Head, Conflict of the Faculties, and On the Philosopher's Medicine of the Body. As was typical in the seventeenth and eighteenth centuries, Kant makes various attempts at classifying mental disorders (Lindeman 1999, 22-23 and Munsche and Harry 2012, 224). Kant's main taxonomy appears in the Anthropology in Book I "On the cognitive faculty." There Kant identifies defects of the cognitive faculty as either "mental deficiencies" or "mental illnesses" (Anth 7: 202). The list of mental deficiencies is wide ranging and seems to have no systematic classification, although Kant does divide the illnesses into either "melancholia" or "mental derangement" (Anth 7: 204-212). Mental derangement then admits of a further division into amentia, dementia, insania, or vensania (Anth 7:215). In the

\footnotetext{
${ }^{1}$ Here I will be drawing heavily on Frierson's account (2009a, b, 2014).

${ }^{2}$ Kant usually uses the terms Krankheit des Gemüths or Gemüthskrankheit for "mental illness." The term Gemüt is translated into English as "mind," but it has a wider connation that may not be properly captured in the English translation. For a helpful explanation, see Rohden (2012). As Rohden argues, the nuances of the term seem to cause the most confusion in Kant's aesthetics, but elsewhere Kant uses it to denote a wide and neutral word for thinking. In the discussion of mental illness, I think Kant intends this wider connation. Thanks to Ansgar Lyssy for asking about this.
} 
earlier Maladies, the classification is slightly different. At first, Kant starts with a division that resembles the Anthropology's: cognitive defects are either "impotency" or "reversal" (Maladies 2: 263). Kant's descriptions of the difference between these two seem to match the differences between deficiency and illness. Once Kant starts to describe the frailties in more detail, however, he uses a three-fold classification. "Derangement" is "the reversal of the concepts of experience" (Maladies 2: 264). "Dementia" occurs when "the power of judgment is brought into disorder" (Maladies 2: 264). Finally, "insanity" happens when "reason has become reversed with respect to more universal judgments" (Maladies 2: 264).

How seriously should we take Kant's taxonomy? Although Kant's classification in the Anthropology seems earnest, it seems less so in Maladies. In the beginning of Maladies, Kant writes, "I see nothing better for me than to imitate the method of physicians, who believe they have been very helpful to their patient when they give his malady a name, and will sketch a small onomastic of the frailties of the head" (Maladies 2: 260). Kant appears to be sarcastic here: it does not actually help a mental patient when we name his malady, but Kant will follow this convention anyway. This line also appears after he makes the joke that "doctors of the understanding, who call themselves logicians" have "made the important discovery: that the human head is actually a drum which only sounds because it is empty" (Maladies 2: 260). Kant is not sarcastic in the Anthropology, but we see at least one hint of hesitation. In the case of derangement, he says that it is "difficult to bring systematic division into what is essential and incurable disorder" (Anth 7: 214). Kant explains that it is a mistake to become too preoccupied with classification because "all methods of cure in this respect must turn out to be fruitless" (Anth 7: 214). Kant's skepticism about the taxonomy is consistent with the pragmatic goals of his account of mental illnesses. The point of examining them is for the purposes of understanding ourselves and each other as well as working to prevent such disorders. If the taxonomy does not serve these purposes, then it has little point.

Given Kant's historical context, I suggest that we ought not see the taxonomy as particularly stringent. This is not to say that we ought to ignore Kant's distinctions; rather, we will gain more from his discussion by examining how he describes the differences between mental illnesses rather than the categories into which he places them. It is difficult to render systemically Kant's views about mental illness, but the main feature of Kant's account of mental disorder is its focus on the pragmatic (Frierson 
2009a, 269). The question we face is how exactly to understand the pragmatic dimension of his account of mental illness.

\subsection{The Pragmatic Dimensions of Mental Illness}

As Kantians have argued, Kant's approach to anthropology is pragmatic rather than physiological (Frierson 2009b, 293-295; 2014, 206-208; Cohen 2017, 263-264). Kant's vision for anthropology is an investigation of what "a free-acting being makes of himself, or can and should make of himself" (Anth 7: 119). If we think of Kant's account of mental illness as consistent with this commitment, we can construct three possible ways of understanding what "pragmatic" means in this case.

One possibility is that Kant's aim is clinical: perhaps he describes mental disorders so that readers can learn how to avoid them. ${ }^{3}$ This interpretation faces some challenges. For example, as Frierson points out, we should expect Kant to provide more extensive details on prevention of mental disorder, but those details are lacking (Frierson 2009b, 293). In some places, Kant seems to suggest that some mental disorders are heredity and incurable (Anth 7:214; Maladies 2: 263). If we take these comments at face value, then it is hard to see what advice readers are meant to take away. Additionally, Kant is clear that it is wrong to attribute someone's mental disorder to bad behavior. In a lengthy passage in Maladies, he writes:

I cannot even in any way convince myself that the disturbance of the mind originates from pride, love, too much reflection, and who knows what misuse of the powers of the soul, as is generally believed. This judgment, which makes of his misfortune a reason for scornful reproaches to the diseased person, is very unkind and is occasioned by a common mistake according to which one tends to confuse cause and effect. When one pays attention only a little to examples, one sees that first the body suffers, that in the beginning, when the germ of the malady develops unnoticed, an ambiguous reversedness is felt which does not yet give suspicion of a disturbance of the mind, and which expresses itself in strange amorous whims or inflated demeanor or in vain melancholic brooding. With time the malady breaks out and gives occasion to locate its ground in the immediately preceding state of mind. (Maladies 2: 270-1)

\footnotetext{
${ }^{3}$ I take the term "clinical” from Frierson $(2009 b, 293)$.
} 
Similar comments appear in the Anthropology: "People often claim to know how to indicate the accidental causes of this illness [madness], so that it may be represented not as hereditary but rather as acquired, as if the misfortunate one himself were to blame for it" (Anth 7:217). Kant claims that people mistakenly think certain behaviors cause madness when in reality it "presupposes a madness, without which he would not have fallen into such behavior" (Anth 7:217). If we are not to blame for falling prey to some mental disorders, then to what extent are we supposed to be responsible for preventing them?

Another way to understand the pragmatic dimension of Kant's account is encyclopedic. ${ }^{4}$ There is some reason to think that Kant was interested in improving anthropology in this way: in a 1773 letter to Herz he writes that he intends to make anthropology into a "proper academic discipline" (Correspondence 10: 145). We know that Kant was particularly critical of anthropological theories in his time. He was opposed to physiological approaches, like those found in Platner and Descartes, which he refers to as "a pure waste of time" (Anth 7: 119) and "eternally futile inquiries" (Corr 10: 145). ${ }^{5}$ If he seeks a better alternative, then his discussion of mental illness may be in the service of developing the "proper academic discipline." This interpretation would also explain why Kant offers a taxonomy of mental disorder. His attempts at classification might be in the hopes of establishing rigor. Nosology for mental illness was a major theme in the seventeenth and eighteenth centuries, so there is reason to think that Kant was simply continuing in this tradition. ${ }^{6}$ Yet this interpretation is unable to explain why Kant is so insistent that anthropology should be a pragmatic pursuit. Kant acknowledged that the physiological approach to anthropology was useful within the academy (Jacobs 2003, 111-112; Louden 2011, 67-68). Although Kant likely thought that the academy could benefit from his account, he seemed to be calling for an anthropology that is concerned with what "comes after our schooling" (Anth 7: 120). Further, his letter to Herz notwithstanding, Kant was particularly skeptical of the possibility of making anthropology into a proper science. One reason had to do with the type of knowledge it was: because its subject matter is ordinary human life, anthropology can only ever admit of

${ }^{4}$ I take this term from Jacobs $(2003,114)$.

${ }^{5}$ For more on Kant's critique, see Jacobs (2003), Frierson (2009a), Louden (2011), and Zinkstok (2011).

${ }^{6}$ See Munsche and Harry $(2012,226)$. 
empirical certainty, which is insufficient for real science (Jacobs 2003, 109-110). Additionally, anthropology requires humans to observe themselves in order to reach its conclusions, and Kant has reservations about this methodology (Jacobs 2003, 110-111; Frierson 2014, 4-6). Even though Kant is certainly interested in anthropology and sees it as important, the challenges he identifies to making it a proper science appear insurmountable.

If the clinical and encyclopedic interpretations face difficulties, perhaps Kant's description of mental illness is better understood as part of his moral anthropology. In the preface to the Anthropology, Kant contrasts his approach to that of the physiologist. While the physiologist might study memory, for example, by thinking about "traces of impressions remaining in the brain" or "cranial nerves and fibers," the pragmatic anthropologist will study the memory in order to know "what has been found to hinder or simulate memory in order to enlarge it or make it agile" (Anth 7: 119). The example of memory helps explain how anthropology might be tied to Kant's moral project. Understanding how memory works can help us to cultivate or refine it. Kant argues that part of the project of virtue is to develop ourselves, which includes our natural talents, our cognitive capacities, and our physical powers (MM 6: 419, 444). Anthropology involves learning about all these sorts of capacities. As Louden describes it, when we "choose to use our knowledge of human nature for moral purposes [... our anthropology becomes a moral anthropology" (2011, 69 emphasis original). What does the moral anthropology interpretation tell us about Kant's remarks on mental illness?

At first glance, the moral anthropology reading seems the most promising. Kantians have argued that Kant's approach to anthropology can be best understood as an application: the knowledge that we gain from anthropology is supposed to aid us in our practical life and dealings with others (Louden 2011; Schmidt 2005; Cohen 2014). Scholars have argued that Kant's remarks on affects and passions (Louden 2011, 70-71; Frierson 2009b, 297-298), temperaments (Cohen 2017, 266-268), and character (Schmidt 2007, 179-177; Frierson 2009b, 298; Louden 2011, 73-75) help to spell out these conditions. Kant's remarks on mental illness at first seem to be part of the same task. For example, Frierson points out that both affects and passions, which Kant calls illnesses of the mind, ${ }^{7}$ are

\footnotetext{
7 "To be subject to affects and passions is probably always and illness of the mind because both affect and passion shut out the sovereignty of reason" (Anth 7:251, emphasis original).
} 
hindrances to morality (2009b, 296-298). Cohen argues that each of the four temperaments (sanguine, choleric, melancholic, and phlegmatic) are accompanied by various cognitive pitfalls, which we need to be aware of in order to cultivate our cognitive capacities in the service of morality (2017, 263-266). Along these lines, we might think that mental disorders pose moral obstacles and that anthropological knowledge of them will help us avoid or overcome those obstacles.

Before we proceed, we should note a few caveats. As we have seen earlier in this volume, the notion of moral anthropology in Kant's work is debated (Sensen, Chap. 5 and Louden, Chap. 7). ${ }^{8}$ There is always the looming question about the relationship between Kant's commitments to pure moral philosophy and the empirical world of the human. ${ }^{9}$ With regard to mental illness in particular, this interpretation faces the same challenge as the clinical interpretation. It is unclear how much responsibility Kant thinks we bear for preventing mental disorder and Kant does not provide many details about how to develop mental health. Additionally, it is not immediately clear how mental illness relates to moral anthropology. One of the places where Kant discusses moral anthropology directly is in the Metaphysics of Morals in the section entitled "On the Relation of the Faculties of the Human Mind to Moral Laws" (MM 6: 211). Predictably, we find the faculty of pleasure and displeasure and the faculty of desire discussed here. Mental illnesses are classified under the faculty of cognition and it is notably absent from this section. Kant's division in the Anthropology appears to confirm that the cognitive faculty is correctly left out. Affects and passions appear in Book III, which covers the faculty of desire (although the affects are actually housed in the faculty of pleasure and displeasure). ${ }^{10}$ Mental illnesses are discussed in Book I, which covers the faculty of cognition. Character and temperament appear in the second

\footnotetext{
${ }^{8}$ For more on the debate, see Frierson (2014), Louden (2011), Cohen (2017), and Schmidt (2007).

${ }^{9}$ Louden suggests that Kant's views about the purity of morality shifted over time (Louden 2011, 66). Cohen points out this challenge, but agrees with Louden that if anthropology is used to help apply morality in practice, it does not threaten the purity of Kant's moral theory (Cohen 2017, 257). Schmidt argues that the tension is resolved because once we realize that Kant means two different things when he talks about anthropology being an "application" of morality (Schmidt 2005, 70-73).

10 "In this section, we should also deal with affects as feelings of pleasure and displeasure. ... But since these are often confused with the passions [...]. I shall undertake a discussion of them when the occasion arises in the third section" (Anth 7:235).
} 
part of the Anthropology. Although Cohen is correct to point out that natural temperaments and character have associated cognitive weaknesses, it is difficult to draw conclusions about the relationship between temperament and mental illness. Kant discusses melancholy in both places, but there is no necessary relationship between melancholy as mental illness and melancholy as a temperament. The melancholic person is "disposed to melancholy" but this is different from "the person afflicted with melancholy, for this signifies a condition" (Anth 7: 288). Moreover, Kant identifies the temperaments as involving "the faculties of feeling and desire" (Anth 7: 286). This classification would support the conclusion from the Metaphysics of Morals that the faculties of mind connected to morality are primarily feeling and desire.

Caveats aside, both the clinical interpretation and the moral anthropology interpretation capture important insights about Kant's account of mental illness. They both correctly identify Kant's account of mental illness as having normative dimensions. The question is how best to understand and articulate those dimensions. Expanding on both of these interpretations, I will argue that Kant's account of mental illness is best understood as part of the project of the applied logic. ${ }^{11}$

\subsection{Applied Logic and Mental Illness}

In order to show that mental illness is part of applied logic, I should first explain Kant's account of applied logic. In the first Critique, Kant divides logic into its "general" and "particular" uses (CpR A52/B76). Applied logic is a type of general logic and is "directed to the rules of the use of the understanding under the subjective conditions that psychology teaches us" ( CpR A53/B77). Kant explains that because applied logic has "empirical principles" and cannot be "a canon of the understanding in general nor an organon of particular sciences," but rather "a cathartic of the common understanding" (CpR A53/B77-8). What does it mean for applied logic to be a cathartic? Kant writes:

It deals with attention, its hindrance and consequences, the cause of error, the condition of doubt, of reservation, of conviction, etc., and the general and pure logic is related to it as pure morality is related to the doctrine of

${ }^{11}$ For arguments about the relationship between Kant's anthropology and applied logic, see Zinkstok (2011) and Cohen (2018). 
virtue proper, which contains merely the necessary moral laws of a free will in general, is related to the doctrine of virtue proper, which assesses these laws under hindrances of the feelings, inclinations, and passions to which human beings are more or less subject, and which can never yield a true and proven science, since it requires empirical and psychological principles just as much as that applied logic does. (CpR A54/B78-A55/B79)

Pure logic and applied logic relate to each other just as the laws of morality relate to the doctrine of virtue. Both applied logic and the doctrine of virtue must have some empirical content; they both "assess" what the pure laws of their respective domains look like in real human life. The aim of applied logic is to understand what thinking looks like in actual human beings and to identify the pitfalls we face in trying to organize our thinking according to the pure laws of logic. ${ }^{12}$ The point of this examination is to help us improve our thinking and to correct error. Applied logic "says what one ought to do in order to make correct use of the understanding under various subjective obstacles and restrictions; and we can also learn from it what furthers the correct use of the understanding, the means of aiding it, or the cures for logical mistakes and errors" (Jäsche 9: 18). The parallels that Kant draws between applied logic and the doctrine of virtue are instructive. As Kant writes in the Metaphysics of Morals, he thinks of virtue as a kind of strength to resist "obstacles within the human being's mind" that will prevent her from doing her duty (MM 6: 380). Kant scholars have argued that applied logic likewise has as one of its tasks the identification of the sources of error in our thinking (Lu-Adler 2017, 222-226, Cohen 2018, and Merritt 2018). For example, there are extended discussions of prejudice as the source of error in the Blomberg, Vienna, Dohna-Wundlacken, and Jäsche logic lectures (Blomberg 24: 161-194, Vienna 24: 862-879, Dohna 24: 737-742, and Jäsche 9: 75-81). In order for us to think well, we must be familiar with the obstacles we will encounter that might prevent us from doing so. Schmidt argues that Kant's discussion of applied logic in the first Critique is designed to be part of a "project of improvement" that Kant continues in Book I of the Anthropology (Schmidt 2005, 71). Book I is of course the book where Kant discusses cognition and it is where the remarks on mental illness appear.

\footnotetext{
${ }^{12}$ For arguments to further support this claim, see Schmidt “Anthropological Dimensions," Zinkstok (2011) and Lu-Adler (2018).
} 
In Book I, Kant includes his discussion of mental illness under the broader category of "defects of the cognitive faculty" (Anth 7: 202). He divides the defects into either "mental deficiencies" or "mental illnesses" (Anth 7: 202). Mental illnesses are then divided again into "melancholia (hypochondria)" or "mental derangement (mania)" (Anth 7: 202). Both types of mental illnesses are characterized by disordered thinking, but what distinguishes them is the way thinking is disordered. Kant claims that in the case of melancholia "the patient is well aware that something is not going right with the course of his thoughts" whereas in the case of mental derangement, there is "an arbitrary course in the patient's thoughts" (Anth 7: 202). As I mentioned above, we should be wary of reading too much in to Kant's taxonomy. I suggest that the specific taxonomy is less illuminating than the two modes of disordered thinking that characterize the two main types of mental illness. Indeed, this part of Kant's account is the most consistent across the works where he discusses mental illness: some mental illnesses involve disordered thinking that the subject can identify as disordered while others involve disordered thinking that the subject does not or cannot identify as disordered.

In On the Philosopher's Medicine of the Body, Kant marks the distinction by asking whether "the mind has been dethroned" (Medicine 15: 943, marginal notes). If it has been dethroned, Kant claims that these patients "should be committed to the care of doctors rather than philosophers, since the mind, displaced from its throne, is not sufficiently aware of the rules of a sound mind-for this, the mind has to be in control of itself" (Medicine 15: 945). Here we see the same notion that appears in the Anthropology; the patient cannot even tell that her thinking has become disordered, so there is no point in trying to help her think better. Similarly, in On the Conflict of the Faculties, Kant claims that medicine is philosophical "when the sheer power of man's reason to master his sensuous feelings by a self-imposed principle determines his manner of living" and it is empirical when it "seeks the help of external physical means (drugs or surgery) to stimulate or ward off these sensations" (Conflict 7: 101). This distinction is similar to the other works, but Kant talks more in terms of control. Philosophical medicine is for mental illnesses that can be managed by reasoning better while empirical medicine is for mental illnesses that require external management. Obviously, philosophical medicine will only work on someone who is still capable of guiding her thinking. In contrast to some of the other taxonomies, Kant claims that hypochondria is the "exact opposite of the mind's power to master its pathological feelings" 
and the "weakness of abandoning oneself despondently to general morbid feelings that have no definite object (and so making no attempt to master them by reason)" (Conflict 7: 103). Oddly, Kant then writes, "As long as a man is afflicted with this sickness we cannot expect him to master his morbid feelings by sheer resolution; if he could do this, he would not be a hypochondriac" (Conflict 7: 103-104). On the one hand, it appears that hypochondriacs make no attempt to master their sensations, and yet it is also a mistake to think that they can merely resolve to better control their feelings once they are in the midst of the affliction. Kant's remarks here demonstrate one of the nuances of his views on mental illness. Although we are responsible for keeping our thinking ordered, it does not follow from this that we can reorder our thinking by sheer force of will once our thinking becomes disordered. Once our thinking becomes disordered, we may need external interventions of the sort that empirical medicine uses. In Kant's own case of managing his hypochondria, he reports that he was helped by a "purely mechanical" explanation of the cause of his morbid thoughts: his "flat and narrow chest" leaves "little room for the movement of the heart and lungs" (Conflict 7: 103). As Kant explains: "The oppression has remained with me, for its cause lies in my physical constitution. But I have mastered its influence on my thoughts and actions by diverting my attention from this feeling, as if it had nothing to do with me" (Conflict 7: 104). Kant could not, without the help of this mechanical explanation, simply pull himself out of his hypochondria by the power of reason alone. He needed the mechanical explanation to help divert his attention away from thoughts about imagined illnesses. Yet the hypochondriac can tell that something is wrong with his thinking even if he cannot reason himself straight.

In Essay on the Maladies of the Head, it is harder to see the two types of disordered thinking, but it is the earliest essay and also the essay where Kant is the most flippant about the idea of categorizing mental illness (Maladies 2: 260, 2: 264). There is, however, some textual evidence that supports the division I have suggested. Like the Anthropology, Kant's discussion of mental illness in Maladies follows his discussion of mental deficiency. He marks the distinction between the two this way: "I come now from the frailties of the head which are despised and scoffed at to those which one generally looks upon with pity" (Maladies 2: 263). Why is the first set of frailties despised and the other pitied? Recall the lengthy passage I cited earlier. Kant writes that he cannot bring himself to believe that the latter afflictions originate in "who knows what misuse of the powers of the 
soul" because such a claim results in "scornful reproaches to the diseased person," which Kant describes as "very unkind" (Maladies 2: 270). Kant seems to suggest that this judgment is unkind because the afflicted person is suffering from this misfortune through no fault of his own. He explains: "When one pays attention only a little to examples, one sees that first the body suffers, that in the beginning, when the germ of the malady develops unnoticed, an ambiguous reversedness is felt which does not yet give suspicion of a disturbance of the mind, and which expresses itself in strange amorous whims or inflated demeanor or in vain melancholic brooding" (Maladies 2: 271). I think the phrase "ambiguous reversedness" is telling. I have suggested that the main difference Kant marks between mental disorders is whether the patient can tell something is wrong with his thinking. Here Kant seems to suggest that a physical cause ("the body suffers") gives rise to the early stirrings of the mental illness ("the germ of the malady develops"), but that this early stage can easily go unnoticed. The patient may start to experience disordered thinking, but not in a way that would raise particular alarm. It would show up as "strange amorous whims" or "inflated demeanor" or "melancholic brooding." At this stage, the patient might be able to tell that something is not right with her thinking, but if she does nothing about it, the disorder in her thinking can become more severe. In Maladies, Kant seems to suggest that disordered thinking of which the patient is aware can, if left unaddressed, become disordered thinking of which the patient is unaware. ${ }^{13}$ This claim is consistent with his remarks in the Conflict essay that once thinking becomes disordered enough, it may be beyond the patient's abilities to re-order her thinking using reason alone. This would explain why Kant thinks it is unkind to reproach the person suffering from conditions such as dementia and insanity. Although Kant does not suggest elsewhere that the two types of disordered thinking are related in this way, the Maladies essay can still be read as consistent with the account I offer here.

At the end of his discussion of mental illness in the Anthropology, Kant claims that all forms of madness have only one "universal characteristic," which is "the loss of common sense (sensus communis) and its replacement with logical private sense (sensus privatus)" (Anth 7: 219, emphasis original). This loss of common sense occurs in different ways and Kant surveys different explanations throughout his works. Sometimes the culprit is an out-of-control imagination (Medicine 15: 943-944, Conflict 7: 103, Anth

\footnotetext{
${ }^{13}$ See also Maladies 2: 260.
} 
7: 215). Sometimes the cause is some hereditary trait (Medicine 15: 945 , Maladies 2: 271, Anth 7:217). Sometimes the source is some ailment of the body (Medicine 15: 945-946, Maladies 2: 270). My suggestion here is that the causes of disordered thinking are a secondary concern for Kant. Instead, I have argued that the question that is of most importance to him is whether or not the patient knows her thinking is disordered. If we read Kant's remarks about mental illness as belonging to his account of applied logic, we can explain why this would be his primary concern. Applied logic's domain is the application of the rules of thinking in real human life. This project must have an empirical part because we must be able to identify what sorts of obstacles we will face in trying to think well. The person who can tell when her thinking is disordered is in a better position to recover and to aid in her own recovery. Crucially, this does not mean that she will be able to reason herself well. She may need help from others, help from philosophical medicine, and even help from medical interventions. But if she knows something is not right with her thinking, she can find her way back to common sense.

\subsection{Mental Illness And the Diet of the Mind}

As part of the task of the applied logic, Kant's account of mental illness is meant to help identify features of the human condition that will hinder our abilities to think well. Yet Kant seems to go beyond simply identifying the dangers of mental illness. Kant seems to give scattered suggestions that there are steps we can take to help stave off mental illness. For example, Kant warns against the use of psychotropic drugs, since they can artificially induce madness (Anth 7:216). He argues that we should be careful with novels because they can encourage a wild imagination (Anth 7 2: 08). ${ }^{14}$ Kant suggests that philosophers are well-suited to add in the recovery of mental illness by prescribing a "diet of the mind" (Maladies 2: 271). Kant clearly thinks that there are steps we can take to help ourselves prevent or manage our disordered thinking. Given the account I've offered here, what does this diet of the mind look like?

First, it is clear that Kant does not believe people can reason their way out of mental illness. Even those who know their thinking is disordered are not always capable of simply talking themselves out of it-Kant gives his own hypochondria as an example (Conflict 7: 103-104). Moreover, it

\footnotetext{
${ }^{14} \mathrm{Also}$, on the dangers of the imagination, see Medicine 15: 944.
} 
is unkind to blame people who suffer from mental illness for their own affliction. As Kant argues in Maladies, even those who know that something is wrong with their thinking may not know how to fix it, and it is unlikely that the cause of their disordered thinking is some misuse of their mental capacities (Maladies 2: 270). Given these commitments, there is an apparent tension in Kant's account. On the one hand, we are usually not responsible for becoming afflicted with mental illness and we cannot reason our way to a cure. On the other hand, we are supposed to take preventative steps from allowing our thinking to become disordered. How can we reconcile these two aspects of Kant's view?

My suggestion is twofold. First, because Kant thinks the only universal characteristic of madness is the substitution of private sense for common sense, the first step to preventing disordered thinking is simply the same requirement that all thinkers have to maintain healthy reason. Kant is clear in several of his writings that the common sense [sensus communis] we lose in madness is a "necessary touchstone (Probierstein)" for our thinking. ${ }^{15}$ As he puts it in the Anthropology, we use the sensus communis to test "the correctness of our judgments generally" and "we also restrain our understanding by the understanding of others, instead of isolating ourselves with our own understanding and judging publicly with our private representations" (Anth 7: 219, emphasis in original). The person with a healthy reason is someone who reasons together with others and who tests her own thinking against the thinking of others. ${ }^{16}$ We ought not, on Kant's view, isolate ourselves and rely too heavily on our private judgment, and this is true for all thinkers in general. This practice will of course not guarantee that we will prevent mental illnesses. Kant thinks that it is unlikely that mental illnesses are caused by the misuse of our cognitive faculties. Yet the practice of thinking together with others will make it easier to discover when our thinking has become disordered. Kant is clear that we test our judgments against the judgments of others when we are unsure about our own thinking. We even do this with regard to our sense experiences. Kant writes, "There are also many cases where we do not even trust the judgment of our own senses alone, for example, whether a ringing is merely in our ears or whether it is the hearing of bells actually being rung, but find it necessary to ask others whether it seemed the same to them"

\footnotetext{
${ }^{15}$ See also CpR A820/B848, Blomberg 24: 188, and Vienna 24: 874-876.

${ }^{16}$ For further arguments about this requirement of thinking well on Kant's view, see Gelfert (2006) and Pasternack (2014).
} 
(Anth 7: 129). To use Kant's example, if it turns out no one else hears ringing that $\mathrm{I}$ hear, this might be a sign that something is wrong either with my ears or with my sense experience. I will only know if something is amiss if I check my own judgments against the judgments of others. This part of the diet of the mind is no different from Kant's general requirement that we take steps to develop a healthy reason. Although it will not cure mental illnesses or prevent them entirely, it will at least help alert us to the possibility that our thinking has become disordered.

Second, Kant can consistently recommend that patients afflicted with mental illness should participate, as much as they can, in their own recovery. Even though, for example, the hypochondriac cannot master his morbid thoughts by sheer force of will, he can nevertheless play an active role in managing his disordered thinking. Sometimes this participation will take the form of seeking medical interventions. Kant is clear that doctors can play a significant role in alleviating the suffering of people with mental illness. Doctors can provide "remedies which might relieve the mind by attending to the body; by driving diseases from the mind or warding them off, these remedies could keep its health guarded and in good repair" (Medicine 15: 946). When diseases of the mind are caused by diseases of the body, a doctor's prescription for bodily health can help address mental health. Kant also claims that doctors can "produce an effective, healthful medication that will help the body by working directly on the mind, cheering it up or alleviating worries by suppressing, or even stimulating affects" (Medicine 15: 946). In other words, even mental illnesses that are not caused by a bodily illness can be effectively treated by medication designed to affect the overall health of the mind. On Kant's view, there is no reason that a patient suffering from a mental illness should not seek out these kinds of interventions. Additionally, Kant's own battles with hypochondria provide an example of non-medical intervention that the patient can use. As he points out, he has never been cured of his illness: "The oppression has remained with me, for its cause lies in my physical constitution" (Conflict 7: 104). Nevertheless, the explanation that his narrow chest is the cause of his morbid feelings has allowed him to master hypochondria's influence "by diverting my attention from this feeling" (Conflict 7: 104). When Kant starts to experience morbid feelings, he uses the mechanical explanation of his illness to help him divert his attention away from it. He is not simply reasoning his way out of his morbid feelings. He is providing his attention with a different object on which to focus so that it does not exacerbate his morbid feelings. This sort of intervention is consistent with 
Kant's claim that we cannot by sheer resolution reorder our thinking even if we know it is disordered. We cannot think ourselves well, but this does not mean that we cannot help ourselves get better.

\subsection{Conclusion}

I have argued that Kant's account of mental illness is better understood as part of his applied logic. On Kant's view, we must be aware of the possible obstacles we will face in trying to be good human thinkers. Mental illness is one of those possible obstacles. I have argued further that, contrary to popular thinking, Kant does not think we can master our mental illnesses through sheer force of will. On Kant's view, the causes of mental illness are varied and they are not caused by the misuse of our cognitive abilities. Even though we cannot reason ourselves out of mental illness, Kant thinks there are ways we can actively participate in our own mental recovery and management. Contrary to popular readings of Kant as a champion of reason's power, Kant's conception of mental illness shows that he recognizes how fragile human reason can be.

\section{REFERENCES}

Cohen, Alix. 2014. The Anthropology of Cognition and Its Implications. In Kant's Lectures on Anthropology: A Critical Guide, ed. Alix Cohen, 76-93. New York: Cambridge University Press.

- 2017. The Natural, the Pragmatic, and the Moral in Kant's Anthropology: The Case of Temperaments. Early Science and Medicine 22: 253-270.

- 2018. Kant on Science and Normativity. Studies in History and Philosophy of Science 71: 6-12.

Foucault, Michel. 2008. Introduction to Kant's Anthropology. Trans. Roberto Nigro and Kate Briggs. Los Angeles: Semiotext(e)/MIT Press.

Frierson, Patrick. 2009a. Kant on Mental Disorder Part 1: An Overview. History of Psychiatry 20 (3): 267-289.

- 2009b. Kant on Mental Disorder Part 2: Philosophical Implications of Kant's Account. History of Psychiatry 20 (3): 290-310.

- 2014. Kant's Empirical Psychology. New York: Cambridge University Press.

Gelfert, Axel. 2006. Kant on Testimony. British Journal for the History of Philosophy 14 (4): 637-652.

Jacobs, Brian. 2003. Kantian Character and the Problem of a Science of Humanity. In Essays on Kant's Anthropology, ed. Brian Jacobs and Patrick Kain, 105-134. New York/Cambridge: University Press. 
Lindemann, Mary. 1996. Health and Healing in Eighteenth-Century Germany. Baltimore: Johns Hopkins University Press.

- 1999. Medicine and Society in Early Modern Europe. Cambridge: Cambridge University Press.

Louden, Robert. 2011. Kant's Human Being: Essays on his Theory of Human Nature. New York: Oxford University Press.

Lu-Adler, Huaping. 2017. Kant and the Normativity of Logic. European Journal of Philosophy 25 (2): 207-230.

- 2018. Kant and the Science of Logic: A Historical and Philosophical Reconstruction. New York: Oxford University Press.

Merritt, Melissa McBay. 2018. Kant on Reflection and Virtue. New York: Oxford University Press.

Munsche, Heather, and Whitaker Harry. 2012. Eighteenth Century Classification of Mental Disorders: Linneaus, de Sauvages, Vogel, and Cullen. Cognitive and Behavioral Neurology 25: 224-239.

Pasternack, Lawrence. 2014. Kant on Opinion: Assent, Hypothesis, and the Norms of General Applied Logic. Kant-Studien 105: 41-82.

Rohden, Valerio. 2012. The Meaning of the Term GEMÜT in Kant. In Kant in Brazil, ed. Frederick Rauscher and Daniel Omar Perez, 283-294. Suffolk: Boydell \& Brewer.

Schmidt, Claudia. 2005. The Anthropological Dimensions of Kant's Metaphysics of Morals. Kant-Studien 96: 66-84.

- 2007. Kant's Transcendental, Pragmatic, Empirical, and Moral Anthropology. Kant-Studien 98: 156-182.

Unna, Yvonne. 2012. A Draft of Kant's Reply to Hufeland: Key Questions of Kant's Dietetics and the Problem of Its Systematic Place in His Philosophy. Kant-Studien 103: 271-291.

Wiesing, Urban. 2008. Immanuel Kant, His Philosophy of Medicine. Medicine, Health Care and Philosophy 11: 221-236.

Zammito, John. 2018. Kant and the Medical Faculty: On 'Conflict of the Faculties'. Epoché 22 (2): 329-451.

Zinkstok, Job. 2011. Anthropology, Empirical Psychology, and Applied Logic. Kant Yearbook 3 (1): 107-130. 